УДК 351.746

\title{
Покращення організаційної структури прикорАонної служби України
}

\author{
I.M. CABEHKO \\ Аьвівський регіональний інститут Аержавного управління Національної \\ акалемії державного управління при Презилентові України, \\ м. Аьвів-Брюховичі, Україна, E-mail: lena.savenko@gmail.com
}

\begin{abstract}
Авторське резюме
У статті розглянуто основні чинники, які зумовлюють необхідність удосконалення організаційної структури прикордонної служби України. Визначено основні напрями удосконалення організаційної структури прикордонної служби України та подано їх характеристику. Окремий акцент поставлено на потребі перегляду правового статусу Державної прикордонної служби та її виведення з підпорядкування Міністерству внутрішніх справ України. Представлено основні шляхи вдосконалення кадрової політики в органах прикордонної служби. Обгрунтовано, що нова структура прикордонної служби України вимагає розробки нових типових схем управління. Подано пропозиції щодо вирішення проблеми ротації кадрів, стабільності роботи в органах прикордонної служби, наукового забезпечення здійснення ефективної роботи працівниками прикордонної служби та понесення відповідальності за скоєння ними неправомірних дій у процесі виконання своїх обов'язків.
\end{abstract}

Ключові слова: державне управління, прикордонна служба, організаційна структура, механізми, охорона державного кордону.

\section{Improvement of organizational structure of boundary service of Ukraine}

\author{
I.M. SAVENKO \\ Lviv regional institute of public administration, the National Academy \\ of public administration, office of the President of Ukraine, \\ L'viv-Bryuxovy`chi, Ukraine, E-mail: lena.savenko@gmail.com
}

\section{Abstract}

The article examines the main factors that determine the need to improve the organizational structure unification governing the activities of the Border Service of Ukraine. The main directions of improvement of the organizational structure unification of the Border Service of Ukraine and submitted their characteristic. Special emphasis is placed on the need to review the legal status of the State Border Service and its withdrawal from the jurisdiction of the Ministry of Internal Affairs of Ukraine. The basic ways of improving personnel policies at the border guard. Proved that the new structure of the Border Guard Service of Ukraine requires the development of new model management schemes. Suggestions to tackle rotation rate, stability in the border guard, scientific support effective implementation of border guards and officers liability incurred for committing unlawful acts by them in the performance of their duties.

Key words: public administration, Border Guard Service, the organizational structure, the mechanisms of the state border.

Постановка проблеми. Побудова ефективно діючої системи прикордонної служби має бути здійснена на основі уніфікованої організаційної структури iï органів. Основною метою держави при цьому повинно стати приведення структури Державної прикордонної служби України у відповідність до реалій сьогодення, максимально позбутися корупційних проявів та очистити структуру (c) I.M. Савенко, 2015 
від тих, хто неспроможний іти даним шляхом.

Аналіз досліджень i публікацій. Окремі питання, пов'язані 3 діяльністю прикордонної служби України, розглянуто в роботах С. Бабуріна, Ю. Барсегова, Л. Волової, С. Дністрянського, Б. Клименка, А. Мостиського, А. Порланда, А. Щербакова, Т. Цимбалістого та ін. Питання діяльності прикордонної служби піднімають у своїх працях такі науковці, як О. Ананьїн, Ю. Дем'янюк, В. Кириленко, М. Литвин, В. Ліпкан, О. Мельников, Б. Марченко, Л. Серватюк, С. Царенко та інші.

Разом з тим, проблеми та шляхи покращення організаційної структури прикордонної служби недостатньо висвітлені у науковій літературі з державного управління, що потребує поглиблення наукових досліджень у даному напрямі.

Мета дослідження: обгрунтування шляхів покращення та уніфікації організаційної структури прикордонної служби України.

Виклад основного матеріалу. Організаційну структуру прикордонної служби України слід уніфікувати таким чином, що в основі діяльності відомства має стати військовослужбовець-прикордонник, його підготовка, всебічне забезпечення та соціальний захист. У свою чергу, громадяни під час перетину кордону мають відчувати себе захищеними та подорожувати 3 максимальним комфортом. Крім того, метою реформи буде посилення протидії контрабанді та організованій злочинності на державному кордоні.

3 метою реалізації задуманого в Адміністрації Державної прикордонної служби України вже створена робоча група, яка опрацює дорожню карту реалізації реформ. Анонсовані у відомстві зміни спрямовані на виконання в межах компетенції мирного плану Президента України та «Стратегії реформ-2020».

За цей час уже здійснено немало перетворень у прикордонній службі, які докорінно змінили принципи їі функціонування. Так, відбулася оптимізація структури Державної прикордонної служби за основним критерієм «ефективність-вартість» спрямована на ство- рення чотирьохрівневої системи управління: Адміністрація - регіональне управління - орган охорони кордону відділ прикордонної служби.

Проте залишається ще багато роботи, спрямованої на вдосконалення організаційної структури прикордонної служби України. На сьогоднішній день гостро стоїть питання охорони державного кордону, особливо у східному напрямку. За цих умов постало нагальне питання перегляду існуючих підходів до охорони та захисту державного кордону України, оскільки, сповідуючи європейські та євроатлантичні прагнення, українське керівництво наполегливо демілітаризовувало прикордонну охорону прагнучи надати їй статус правоохоронної структури, яка має зосереджуватись виключно на поліцейських функціях при забезпеченні режимів державного кордону та прикордонної смуги. Логічним продовженням такого підходу стало певне поєднання Державної прикордонної служби 3 Міністерством внутрішніх справ України, яке сталось за часів президента Януковича.

Різке зростання терористичної та розвідувально-диверсійної діяльності сепаратистських угруповань за прямої та безпосередньої участі Росії не тільки в прикордонних районах, а й в глибині української території зумовлюють необхідність значного розширення оперативних можливостей Державної прикордонної служби, а також розширення повноважень щодо протидії терористичній та розвідувально-диверсійній діяльності.

Згадані тенденції обумовлюють необхідність перегляду існуючої нормативно-правової бази щодо охорони та захисту державного кордону. При цьому відправним пунктом такої роботи має стати перегляд правового статусу Державної прикордонної служби та її виведення 3 підпорядкування Міністерству внутрішніх справ України. Конституційні рамки правоохоронної діяльності, яка проводиться МВС України, фактично не дозволяють Державній прикордонній службі адекватно реагувати на загрози національній безпеці у сфері ї̈ 
відповідальності. Крім того, необхідність підвищення ефективності координації діяльності військових формувань, правоохоронних органів, органів центральної виконавчої влади, місцевого самоврядування, об'єднань громадян у справі охорони та захисту державного кордону обумовлює необхідність надання статусу Державній прикордонній службі «спеціально уповноваженого органу центральної виконавчої влади», який має відповідний фаховий потенціал для розробки пропозиції з покращення такої взаємодії.

Реалізація зазначених першочергових кроків дозволить розпочати активну роботу щодо вдосконалення підходів 3 охорони та захисту державного кордону. Крім того, Державна прикордонна служба відновить своє рівноправне положення серед інших силових структур держави, які забезпечують національну безпеку та діяльність яких безпосередньо спрямовується Президентом України. Це зробить логічним та зрозумілим входження Державної прикордонної служби до системи управління воєнною організацією держави, що однозначно позитивно позначиться на обороноздатності нашої країни [4].

Загалом, основними цілями та завданнями оптимальної організації прикордонної служби є:

- здійснення ефективної кадрової політики у сфері прикордонної служби;

- науково обгрунтоване планування та прогнозування розвитку персоналу прикордонної служби;

- систематичний аналіз стану та ефективності функціонування прикордонної служби;

- нормативно-правове та організаційне забезпечення комплектування персоналу органів прикордонної служби 3 урахуванням здібностей, професійних досягнень, особистісних і моральних якостей службовців;

- створення та ведення реєстру посад в прикордонній службі;

- розробка i запровадження сучасних типових схем управління та їх методичного забезпечення;

- визначення, унормування і моні- торинг професійно-кваліфікаційних характеристик посад прикордонної служби;

- визначення кваліфікаційних вимог до працівників прикордонної служби;

- формування сучасної інформаційно-аналітичної мережі, яка б містила інформацію про систему нормативних актів прикордонної служби, забезпечувала облік і аналіз персонального складу працівників, моніторинг ефективності діяльності органів прикордонної служби тощо;

- організація та методичне керівництво професійною підготовкою, перепідготовкою, підвищенням кваліфікації та стажуванням працівників;

- створення і запровадження правових механізмів захисту прав та інтересів працівників;

- інформування громадськості про діяльність органів прикордонної служби та її кадрового складу;

- контроль за дотриманням законодавства прикордонної служби та діяльністю її персоналу.

Концептуальних змін потребує характер діяльності структурних підрозділів органів прикордонної служби. Він має бути переорієнтований на виконання провідних функцій - аналізу, прогнозування, оцінки ефективності діяльності органу та його структурних підрозділів, професійної діяльності працівників тощо.

Основними завданнями Адміністрації Державної прикордонної служби України є:

- реалізація державної політики у сфері захисту державного кордону, участь у розробленні та реалізації загальних принципів правового оформлення і забезпечення охорони державного кордону та суверенних прав України в їі виключній (морській) економічній зоні;

- здійснення управління Державною прикордонною службою України;

- розроблення разом із відповідними органами виконавчої влади пропозицій щодо виконання міжнародних договорів з питань дотримання режиму державного кордону;

- координація діяльності військо- 
вих формувань і відповідних правоохоронних органів, пов'язаної із захистом державного кордону України, а також діяльності державних органів, що здійснюють різні види контролю при перетині державного кордону або беруть участь у забезпеченні режиму державного кордону, прикордонного режиму і режиму в пунктах пропуску через державний кордон України;

- здійснення контролю за додержанням вимог законодавства про державний кордон;

- управління територіальними органами, Морською охороною, органами охорони державного кордону, розвідувальним органом, органами забезпечення, навчальними закладами;

- забезпечення оснащення підпорядкованих органів озброєнням і військовою технікою, підготовки і розстановки кадрів, зміцнення дисципліни і правопорядку серед особового складу Державної прикордонної служби України [3].

Нова структура прикордонної служби України вимагатиме розробки нових типових схем управління. При цьому мають бути забезпечені як їх певна достатня прозорість, так і спрощення процедур управління, що дасть можливість визначити оптимальну чисельність персоналу, забезпечить чітку ієрархію та уніфікацію завдань, функцій i повноважень органів прикордонної служби та їхніх структурних підрозділів, їхніх назв, уніфікацію та стандартизацію професійно-кваліфікаційних характеристик посад тощо.

3 цією метою доцільно розробити програму методичного забезпечення типових схем управління та типових структурних підрозділів органів прикордонної служби. Проектування типових структур управління має базуватися на програмно-цільовому та функціональному принципах з урахуванням змісту й характеру праці державних службовців на конкретних посадах в органах державної влади.

Зрозуміло, що ця робота має координуватися на державному та місцевому рівнях. Наслідком запровадження типових структур управління може стати суттєве підвищення керованості, ефективності й результативності органів прикордонної служби.

Актуальною є проблема правового забезпечення кар'єри прикордонника як гарантії стабільності системи прикордонної служби. При цьому вдосконаленню підлягають правові норми, що стосуються умов проходження та просування по службі, питань планування кар'єри, визначення ㄲï етапів та вимог щодо ㄲï успішного завершення, правових гарантій просування по службі та встановлення певних умов щодо його обмеження.

$\mathrm{He}$ менш актуальною $є$ проблема створення науково обгрунтованої системи ротації кадрів (вертикальної та горизонтальної) як чинника набуття необхідного практичного досвіду професійної діяльності та елемента планування кар'єри, її нормативно-правового регулювання.

Важливими складовими правового забезпечення прикордонної служби $\epsilon$ вдосконалення інститутів юридичної відповідальності ї̈ персонального складу, встановлення гарантій їх правового становища, організація правової підготовки працівників прикордонної служби. Це - багатоаспектна проблема, що вимагає скоординованих, комплексних, узгоджених розробок у галузях державного, адміністративного, трудового, кримінального, фінансового права. В українському законодавстві питання захисту прав і інтересів кадрового складу прикордонної служби та юридичної відповідальності працівників мають бути вирішені з прийняттям Кодексу загальних правил поведінки прикордонників.

Вирішення проблем юридичної відповідальності кадрів і в законодавстві, і в практичному плані має бути пов'язане з вирішенням завдань боротьби з корупцією. Заходи боротьби з корупцією необхідно розглядати як невід'ємну складову розвитку правового забезпечення органів прикордонної служби.

Удосконалення правового статусу працівників прикордонної служби має супроводжуватися створенням і запровадженням механізмів їх правової захищеності. Захист прав та інтересів персо- 
нального складу сприятиме досягненню стабільності їх статусу й запровадженню механізмів контролю політичної нейтральності прикордонної служби. Доцільно, поряд з цим, вивчити практику розвинутих країн світу щодо використання інститутів захисту прав, соціально-економічних i професійних інтересів прикордонників через законодавче оформлення можливості їх об'єднання у професійні спілки. Також необхідно передбачити посилення впливу трудових колективів органів прикордонної служби на процеси просування по кар'єрних сходах, присвоєння чергових рангів, атестації тощо, тим самим зробити механізм службової кар'єри об'єктивним, прозорим, відкритим і гласним.

Важливе значення для зміцнення i стабільності прикордонної служби має необхідність реформування системи оплати праці їі працівників. Реформа оплати праці повинна створити необхідні умови для професійного виконання службових обов'язків, укомплектування органів прикордонної служби висококваліфікованими та досвідченими фахівцями, запровадити систему матеріального заохочення за сумлінну та ініціативну працю, змінити іiї характер на інноваційний. Метою цієї реформи є забезпечення конкурентоспроможності прикордонної служби на ринку праці порівняно з роботою в галузях економіки України та інших галузях державного сектора, усунення відомчого та місцевого впливу, запобігання корупції, кардинальне підвищення зацікавленості працівників у продуктивній та якісній, ініціативній та ефективній, сумлінній та відповідальній роботі, у подальшому просуванні по кар'єрі на засадах особистих професійних досягнень.

Законотворчий процес у галузі прикордонної служби сприятиме тому, що з часом, на нашу думку, виникне нова галузь права - право прикордонної служби- зі своїм предметом правового регулювання. Право прикордонної служби має стати регулятором державно-службових відносин у сфері діяльності органів прикордонної служби.

Розвиток правового забезпечення прикордонної служби сприятиме поліпшенню проведення єдиної кадрової політики у цій сфері, спрямованої на зміцнення та оновлення її кадрового потенціалу. Слід зазначити, що особовий склад Державної прикордонної служби України складається із військовослужбовців та працівників Державної прикордонної служби України, що закріплено у статті 14 Закону України «Про Державну прикордонну службу України» [5].

На основі аналізу абзацу 3 статті 14 Закону, де зазначено, що «трудові відносини працівників Державної прикордонної служби України регулюються законодавством про працю, державну службу та укладеними трудовими договорами (контрактами)», працівників Держприкордонслужби можна класифікувати на дві групи: ті, - правовий статус яких визначається трудовим законодавством, та ті - чий правовий статус регулюється законодавством про державну службу.

Удосконалення роботи 3 особовим складом необхідно здійснювати за напрямами створення власної системи комплектування, ефективного використання кадрового ресурсу, реформування системи професійної підготовки та вдосконалення морально-психологічного забезпечення.

Під єдиною кадровою політикою у сфері прикордонної служби слід розуміти стратегію, політичний курс щодо роботи 3 кадрами на загальнодержавному рівні, державну стратегію формування, розвитку та раціонального використання кадрів працівників органів прикордонної служби.

За свідченням фахівців, головні зусилля в роботі з комплектування повинні зосереджуватися на формуванні, постійному поповненні кадрового складу персоналом Державної прикордонної служби України або цивільної молоді, які за станом здоров'я, особистісними якостями здатні навчатись у вищих навчальних закладах, успішно опанувати військову професію і в майбутньому ефективно виконувати завдання за призначенням. Відбір на роботу найбільш 
перспективних людей з маси можливих претендентів - перший і найбільш відповідальний момент у кадровому менеджменті, і його сенс полягає аж ніяк не в оформленні документів при прийомі або звільненні співробітників організації. Його специфічна функція полягає в практичній реалізації кадрової політики, прийнятої керівництвом організації на певний період часу. Враховуючи сказане вище, можна зробити висновок про те, що без ясної, чітко сформульованої кадрової політики не може бути ефективної роботи. Фахівці з практичної психології в економіці та бізнесі О.В. Данчева та Ю.М. Швалб зазначають, що кадрова політика - це не просто перелік вакансій або потрібних робочих місць. Вона $є$ відображенням стратегії розвитку організації в цілому $[1,2]$. Враховуючи їх думку, можна виділити головні завдання в кадровій політиці прикордонної служби:

1. Підбір співробітників (добір кандидатів на вакантну посаду) 3 урахуванням їх відповідності всім головним вимогам конкретної посади та цілям прикордонної служби.

2. Захист прикордонної служби від осіб, потенційно здатних заподіяти шкоду справі захисту державного кордону, іміджу прикордонної служби незалежно від того, свідомо чи ні вони можуть це зробити.

Ця політика повинна бути самостійною і здійснюватися у контексті вдосконалення організаційної структури прикордонної служби таким чином, щоб забезпечувати ефективну підготовку працівників органів прикордонної служби, які можуть виконувати свої службові обов'язки у напрямі гарантування цілісності та недоторканності державного кордону України.

Висновки. Таким чином, реалізація розглянутих першочергових кроків щодо покращення, організаційної структури прикордонної служби дозволить розпочати активну роботу щодо вдосконалення підходів з охорони та захисту державного кордону. До того ж, Державна прикордонна служба відновить своє рівноправне положення серед інших силових структур держави, які забезпечують національну безпеку та діяльність яких безпосередньо спрямовується Президентом України. Це зробить логічним та зрозумілим входження Державної прикордонної служби до системи управління воєнною організацією держави, що однозначно позитивно позначиться на обороноздатності нашої країни.

\section{СПИСОК АITЕРАТУРИ:}

1. Данчева О.В. Практична психологія в економіці та бізнесі / О.В. Данчева, Ю.М. Швалб. - К. : Лібра, 1999. - 270 с.

2. Іщенко Д.В. Шляхи удосконалення кадрової роботи органів управління Державної прикордонної служби / Д.В. Іщенко // Науковий вісник Державної прикордонної служби, № 4. - Хмельницький : Вид-во Національної академії ДПСУ, 2003. - С. 8.

3. Лавринець А. Є. Правове регулювання організації прикордонного контролю в Україні / А. Є. Лавринець // Боротьба з організованою злочинністю і корупцією (теорія і практика). - № 24. - 2011. - с. 305-312.

4. Матвієнко Ю. Вдосконалення законодавчої бази щодо охорони та захисту державного кордону[Електронний ресурс]-Режим доступу : http: //www.dsaua.org/index.php?option=com content\&view $=$ article $\& i d=201 \% 3 \mathrm{~A} 2015-03-18-21-07-51 \&$ catid $=66 \% 3 \mathrm{~A} 2010-12-13-08-48-$ $53 \&$ Itemid $=90 \&$ lang $=u k$

5. Про Державну прикордонну службу України : Закон України - [Електронний ресурс] Режим доступу : http : //zakon2.rada.gov.ua/laws/show/661-15

\section{REFERENCES:}

1. Dancheva O.V. Prakty`chna psy`xologiya v ekonomici ta biznesi (Practical Psychology in economics and business). - K. : Libra, 1999. - 270 p.

2. Ishhenko D.V. Shlyaxy` udoskonalennya kadrovoyi roboty`organiv upravlinnya Derzhavnoyi pry`kordonnoyi sluzhby' (Ways of improving human resources management of the State Border Service) // Naukovy`j visny`k Derzhavnoyi pry`kordonnoyi sluzhby`, № 4. - Xmel`ny`cz`ky`j : 
Vy`d-vo Nacional noyi akademiyi DPSU, 2003. - P. 8.

3. Lavry`necz`A.Ye. Pravove regulyuvannya organizaciyi pry`kordonnogo kontrolyu v Ukrayini (Rights border control organizations in Ukraine) // Borot 'ba z organizovanoyu zlochy nnistyu $i$ korupciyeyu (teoriya i prakty`ka). - № 24. - 2011. - p. 305-312.

4. Matviyenko Yu. Vdoskonalennya zakonodavchoyi bazy` shhodo oxorony` ta zaxy`stu derzhavnogo kordonu (Improving the legal framework on the protection of the state border). Access mode : http : //www.dsaua.org/index.php?option=com content\&view $=$ article\&id $=201 \%$ 3A2015-03-18-21-07-51\&catid $=66 \% 3 \mathrm{~A} 2010-12-13-08-48-53 \&$ Itemid $=90 \&$ lang $=\mathrm{uk}$

5. Pro Derzhavnu pry`kordonnu sluzhbu Ukrayiny`: Zakon Ukrayiny` (On the State Border Service of Ukraine Law of Ukraine). - Access mode : http : //zakon2.rada.gov.ua/laws/show/66115

Савенко Ігор Миколайович - здобувач

Львівський регіональний інститут державного управління

Національної академії державного управління при Президентові України

Адреса: 79491, м.Львів-Брюховичі, вул. Сухомлинського, 16

E-mail: lena.savenko@gmail.com

Savenko Ihor Mykolajovych - applicant

Lviv regional institute of public administration, the National Academy of public administration, office of the President of Ukraine

Address: 16, Sukhomlynsky Str., L`viv-Bryuxovy`chi, 79491, Ukraine

E-mail: lena.savenko@gmail.com 